\title{
Project Based Vocational Skills in Teaching Materials for Physics Education
}

\author{
Susilawati \\ Physics education, PGRI University of Semarang, J1. Sidodadi Timur No. 24 Semarang, Indonesia
}

\begin{abstract}
This research project is based on vocational skills in physics teaching materials for vocational high school students. Vocational skill-based project was developed to improve the skills of vocational students. The series of student activities, scientific activities and assignments designed so as to help students mastering the skills for vocational school. In this study, the research object is the light vehicle engineering and voltage electrical installation techniques. The series of scientific activities and assignment of students was tested in a group of students majoring in engineering light vehicle and a group of students majoring in electrical voltage installation techniques. This research was carried out by quantitative descriptive approach. Observations made during the learning skills of the students. Mastery of the skills of students before and after participating in a series of scientific activities and assignments will be compared. The discussion will be reviewed at each condition and the symptoms that arise during the learning process. The results of this study showed that each of the research subjects experienced an increase in vocational skills, which was showed from assessment of student performance. The results of performance evaluation conducted tests and observation. Performance capabilities after a series of scientific activities and assignments is higher. Based on these results, project-based vocational skills can be recommended to improve the skills of vocational students are ready to work for technology.

Keyword - project based learning, vocasional skill, teaching materials
\end{abstract}

\section{INTRODUCTION}

The importance of students' learning to put their latent skills to optimal use is self-evident as education inculcates decision-making abilities in students. Learning of different subjects may not yield similar results as there are many factors effects students achievement but teaching methods almost have same effect on students learning. Teaching of physics is facing dilemma for teachers as well as students. Physics curricula should inculcate creative thinking and critical analysis in students. Physics students outfitted with crystal-clear concepts should have the proficiencies to solve problems, in the classroom, laboratory, practical problems related to industry, and house-hold real life. Teaching of Physics suffers because due to limited resources, equipment and latest physics books.

Problems in teaching physics can be minimizing by selected suitable teaching method. If one learns physics concepts properly, one should be able to solve unseen problems. The former focus on definitions and derivations, whereas the later emphasize on concept building (Kamal, Arif, 2003). There is no awareness of the importance of physics in the Government officials and among the people (Rashid, Khalid, 2005). Scientific inquiry method brought new developments in the field of education. According Exline, Joe, (2004) scientific inquiry method implies involvement of students that leads to understanding. Furthermore, students' involvement in learning implies possessing skills and attitudes that permit to seek resolutions to questions and issues while you construct new knowledge. "Inquiry" is defined as "a seeking for truth, information, or knowledge seeking information by questioning." Student inquiry is defined as a versatile activity that involves making observations, posing questions, examining books and other sources of information to see what is already known; planning investigations; reviewing what is already known in light of the student's experimental evidence; using tools to gather, analyze and interpret data; proposing answers, explanation, and predictions; and communicating the results.

Inquiry requires of assumptions, use of critical and logical thinking, and consideration of alternative explanations (Exline, Joe, 2003). The present study was intended to scrutinize how the presence of scientific inquiry might affect undergraduate student's achievement in physics. In this study Atkin \& Karplus (1962) Project based vocational is the bases of the Scientific Inquiry method.

\section{METHODOLOGY}

Three instruments used in the study are Physics test and Students' performance. Validity and reliability was ensured through tryout and pilot testing along with content alignment analysis. Content validity was determined by the expert judgment. Physics test was used as pretest and post test to measure students' of the physics topics taught to them during the experiment. Student's intelligence in the form of raw scores was measured by using J.C. Ravens' Standard progressive matrices. The researcher developed performance. Numerical values were assigned to each indicator and total score on test status perfoma was calculated for each sampled student.

Four groups each of 30 students were randomly chosen. Pretest was conducted before experiment to check the group's initial equivalence. The mean of four groups was approximately 20. It validate that all groups were almost same on the pretest. Three experimental groups were taught by the guided scientific inquiry, unguided scientific inquiry, combination scientific inquiry and the fourth control group was taught by the lecture method. Four science teachers of same qualification were selected for the study. Three teachers were trained to teach three experimental groups and fourth teacher assigned to control group of the study for the period of three months. Students of three experimental groups passed through the exploration, concept introduction, 
concept application three phases of the project based vocational.

Students of the first experimental group were given the treatment of guided inquiry and they passed through exploration, concept introduction, concept application the three phases of the project based vocational under the guidance of the teacher. It was teacher directed. Students of the second experimental group were given the treatment of unguided inquiry and learned through their involvement and action. In this group the teacher released the responsibility and it was student directed. The third experimental group was given the treatment of combination (guided/unguided) inquiry, the teacher in this group acted as a facilitator and asked or posed questions, gave ideas. In this approach guided inquiry was followed by unguided inquiry. The main focal point of this cram of research was to actively engage physics students using scientific inquiry in the class. Students were divided into small groups to build up each other's ideas for better understanding. The usages of different apparatus/tools over the three months period provide evidence of advances in the student's scientific inquiry ability. Throughout the study four groups covered the same subject matter. Pretest was conducted as post test to four groups to compare their achievement in physics at the end of the experiment.

\section{DATA ANALYSIS AND DISCUSSION}

The data was collected by using students' performance test and attitudes before the experiment, and physics test was administered as pretest and post test before and after the experiment. Following null hypothesis were tested by analyzing data collected from four groups (Tabel 1).

Table 1 show there is significant difference of scientific inquiry method of teaching and Lecture method of teaching on students' achievement in physics. Scientific inquiry method of teaching is significantly better than lecture method. There is significant difference of guided scientific inquiry method of teaching and Lecture method of teaching on students' achievement in physics. Guided scientific inquiry method of teaching is significantly better than lecture method.

There is significant difference of unguided scientific inquiry method of teaching and Lecture method of teaching on students' achievement in physics. Unguided scientific inquiry method of teaching is significantly better than lecture method. There is significant difference of combine scientific inquiry method of teaching and Lecture method of teaching on students' achievement in physics. Combination scientific inquiry method of teaching is significantly better than lecture method.

There is significant difference of guided scientific inquiry method of teaching and Lecture method of teaching on students' ability to apply knowledge of physics concepts in real life. Guided scientific inquiry method of teaching is significantly better than lecture method. There is significant difference of unguided scientific inquiry method of teaching and Lecture method of teaching on students' ability to apply knowledge of physics concepts in real life. Unguided
Table 1. Data Description

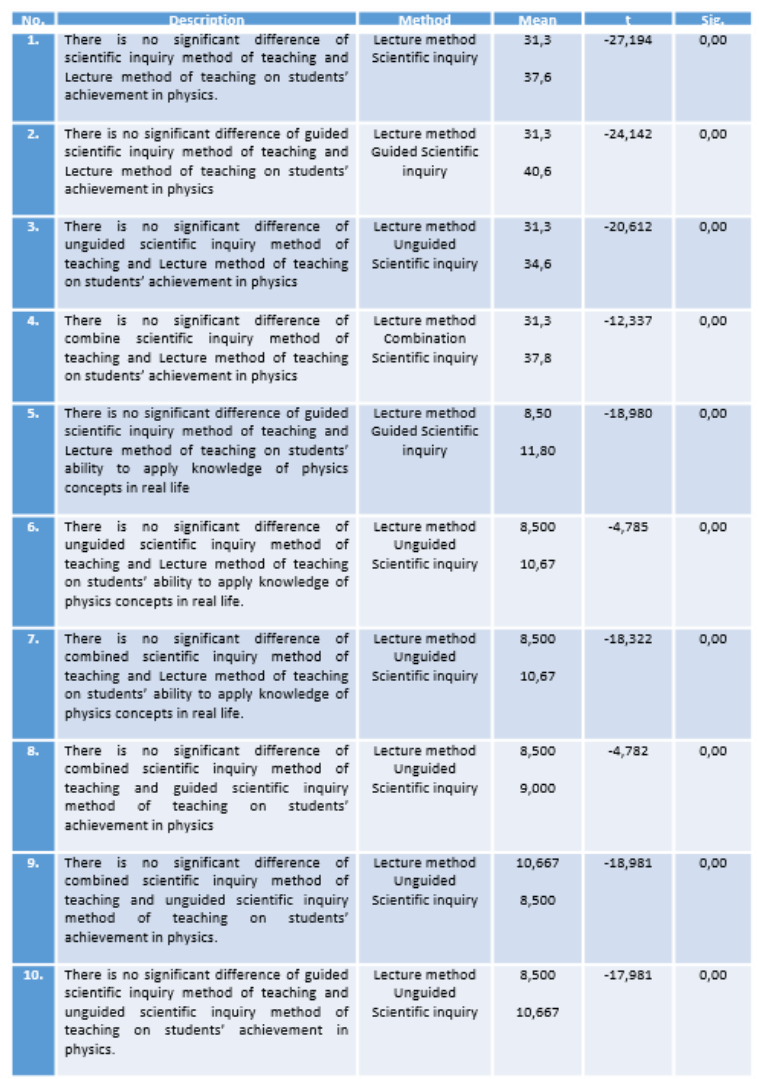

scientific inquiry method of teaching is significantly better than lecture method.

There is significant difference of combined scientific inquiry method of teaching and Lecture method of teaching on students' ability to apply knowledge of physics concepts in real life. Combination scientific inquiry method of teaching is significantly better than lecture method. There is no significant difference of combined scientific inquiry method of teaching and guided scientific inquiry method of teaching on students' achievement in physics. There is no significant difference of combined scientific inquiry method of teaching and unguided scientific inquiry method of teaching on students' achievement in physics. There is no significant difference of guided scientific inquiry method of teaching and unguided scientific inquiry method of teaching on students' achievement in physics.

The differences between the means scores on the physics proficiency test by experimental groups were highly significant and statistically in favour of scientific inquiry. This proved that scientific inquiry is better method of teaching for teaching physics at secondary level. Mean scores of guided scientific inquiry (40.6), unguided scientific inquiry (31.6) and combination scientific inquiry (37.8) were compared with lecture method (34.3). The results of the research indicated that guided scientific inquiry, combination scientific inquiry, and unguided scientific inquiry methods of teaching physics are respectively better than lecture method. In the comparison of guided scientific inquiry, combination scientific inquiry, and unguided scientific inquiry methods it is also found unguided scientific inquiry, combination scientific inquiry, and guided scientific 
inquiry methods are respectively better methods for teaching physics.

These results also supported by the R. M, Goertzen. (2000) research findings on teaching physics by inquiry. This research also signified that the students who taught by the guided, unguided and combination scientific inquiry methods of teaching were better in applying the concepts of physics to real life situations as compared to those students who were taught with traditional lecture method of teaching physics. So it means that the results were highly significant statistically in favour of guided scientific inquiry, unguided scientific inquiry and combination scientific inquiry. All the findings of this research were supported by the research work of Sweller's $(1988,1999)$ supported guided inquiry. Jabot, Michael and Kautz, Christian (2000) compared two different methodological approaches to the teaching of heat and temperature.

\section{CONCLUSIONS AND RECOMMENDATIONS}

According to Hrepic, Zollman \& Rebello ( 2007) lecture is probably the oldest instructional format and today it is still the most common form of instruction. A study by Doucet et al (1998) reported that in the lecture format learners are passive recipients of knowledge in an externally driven process. Traditional lecture method of teaching is teacher centered and students are passive listeners only, where as in modern methods of teaching students are involved in all activities, organized and supervised by the teacher. Peek, Winking and Peek (1995) state that the traditional lecture technique is preferred by many lecturers because it may be perceived as a strategy for establishing and maintaining order in the class and serves as safety net for new teachers who may be unfamiliar with using other methods. The traditional lecture is a more effective way of teaching when a large quantity of information is to be disseminated Miller (2003) and Peek et al (1995). The development of appropriate teaching material for use in the traditional lecture format (Cardoso et al, 2009) could have helped the teacher keep the attention of students. One important difference between a victorious teacher and ineffective teacher is the methods and materials they use in creating interest of their students in their subject. Powell and Kalina (2009) report that the social constructivist theory, involving individual and cognitive constructivism, is a highly effective method of teaching which all students can benefit from since collaboration and social interaction are incorporated.

In the social constructivist classroom there are different approaches such as inquiry, discussion, problem solving, conversation, debate, and cooperative learning. It may be concluded that guided, unguided, and combination scientific inquiry method of teaching is significantly better than traditional lecture method of teaching for the subject of physics. The following recommendations seem to be reasonable and approachable:

a) The research indicated that scientific inquiry method of teaching for the subject of physics is statistically significant than lecture method for teaching physics. It is therefore recommended that teacher education programs may emphasize inquiry teaching method and in-service teachers should be provided training or refresher course to enable them to use scientific inquiry teaching methods in classroom.

b) This research may be replicate for other science and arts subjects.

c) This study may be replicate by including gender variable.

d) This study may be replicate by including location variable

e) More Researches are recommended to compare demonstrate and scientific inquiry methods of teaching physics.

Seminars and conferences may also be organized to disseminate the findings of this research.

\section{REFERENCES}

Anderson, Ronald D. (2007). Inquiry as an Organising Theme for Science Curricula.Abell, Sandra.K. \& Lederman, Norman G. (Eds.), Handbook of research on Science Education (pp807-830).London. Lawrence Erlbaum Associates, Inc.

Beth, Warren, Puttick, Gillian M, Conant, Faith \& Rosebery, Ann S. (1992). Sense making Practices in Science: Case study of an ESL Teacher. Retrieved August 7, 2006, from http://www.exploratorium.edu/IFI/resources/workshops/sense making.html

Budnitz, Norman. (2000). What do we mean by inquiry? Retrieved March 23, 2006, from http://www.biology.duke.edu/cibl/inquiry/what_is_inquiry.htm.

Burnside, Michael .Eric. (2002) Physics Education Research: Summation and Application Retrieved October 2, 2007, from http://physics.ucsc.edu/ josh /burnside/

C.H. Kautz, P.R.L. Heron, M.E. Loverude, and L.C. McDermott, (2005). "Student understanding of the ideal gas law, Part I: A macroscopic perspective," Am. J. Phys. 73 (11) 1055-1063

C.H. Kautz, P.R.L. Heron, P.S. Shaffer, and L.C. McDermott, (2005). "Student understanding of the ideal gas law, Part II: A microscopic perspective," Am. J. Phys. 73 (11) 1064-1071

Committee on Development of an Addendum to the National Science Education Standards on Scientific Inquiry, Center For Science, Mathematics, and Engineering Education, National Research Council .(2000).Retrieved August 25,2005,from http://books.nap.edu/html/inquiry_addendum/index.htm

D.L. Messina, L.S. DeWater, and M.R. Stetzer, (2004). "Helping preservice teachers implement and assess research-based instruction in K-12 classrooms," in Proceedings of the 2004 Physics Education Research Conference, Sacramento CA, August 2004, edited by J. Marx, S. Franklin, and P.R.L. Heron, AIP Conference Proceedings.

Definition: teaching (n.d.). Webster's revised unabridged Dictionary. Retrieved March 15, 2007, from http://dictionary .die.net/ teaching Dictionary of the English Language. (2003). Teaching. Retrieved May 07, 2008, from http://www.thefreedictionary.com/teaching

Dyasi, H. (2006). What Children Gain by Learning through Inquiry. Foundations V.2. Retrieved on 26-12-2006. from http://www.exploratorium.edu/tfi. Education. (2008). In MerriamWebster Online

Edwards, Clifford H. (1997). Promoting Student Inquiry. Retrieved December 25, 2007, from http://www.classtech2000.com/toucan/inquiry/inqtotalmod.htm International Journal of Humanities and Social Science Vol. 1 No. 19; December 2011275

Exline, Joe (2003).Science as Inquiry: Operational Definition Advancing Science As Inquiry. Retrieved October 6, 2004, from http://www.inquiryscience.com/ documents/definition.htm

Exline, Joe. (2004).Concept to Classroom. Retrieved November 6, 2004, from http://www. thirteen.org/edonline/concept2class./inquiry/index.html 
Gagne, R. (1985). The Conditions of learning (4th ed). New York: Holt, Reinhart and Winston.

Gupta, Rajender. (2001). Effective Teaching: Aspects and Techniques.

Retrieved January 7, 2006, from

http://www.newcastle.edu.au/service/teachinglearning/

teachingreview/gupta1.html

Hansen, Lisa Martin. (2002).Defining Inquiry. Exploring the many types of inquiry in the science classroom. Retrieved November 24, 2004, from

http://www.emeraldinsight.com/Insight/manulDocumentRequest.d $\mathrm{o}$ ?hdAction=ref document request\&r_contentId $=0 \& \mathrm{r} \_$atitle $=$Defi ning\%20inquiry\& $r_{-}$jtitle $=$The $\% 20$ Science $\% 20$ Teacher\&r_issn $=\&$ r_year $=2002 \&$ r_volume $=69 \&$ r_issue $=2 \& r_{-}$startpage $=34$ -

$7 \&$ r_endpage $=\&$ r_publisher $=\& \mathrm{r} \_$authors=Martin-Hansen, $\% 20 \mathrm{~L}$.

Hartman, Hope. J. (2001).Metacognition In Science Teaching and Learning. Retrieved March 23, 2008, from

http://condor.admin.ccny.cuny.edu / hhartman/mtscitchghtml

Hasnain, Aziz Fatima. (2004). Physics Education in Pakistan .Retrieved March 23, 2008, from

http://www.aps.org/units/fed/newsletters/fall2004/pakistan.html 